\title{
SUB MAXIMAL OXYGEN UPTAKE RELATED TO FAT FREE MASS AND LEAN LEG VOLUME IN TRAINED RUNNERS
}

\author{
E. M. WINTER, M.Sc., and E. J. HAMLEY, Ph.D. \\ Human Biology Laboratory, the University, Loughborough LE11 $3 T U$
} \begin{abstract}
function.
\section{INTRODUCTION}

Physiological anthropometry has provided a means whereby an understanding, as opposed to a description, of the structure and function of physiological processes may be obtained. Parameters concerned with limb volumes, especially the Fat-Free Mass of a limb have been used and related to the rate of oxygen uptake. Davies (1968), Cotes et al (1969), Jones et al (1969) and Hamley and Watson (1969) have demonstrated the relationships between particular anthropometric indices and maximal rate of oxygen uptake $\left(\mathrm{VO}_{2}\right.$ max) and sub maximal rate of oxygen uptake $\left(\left(\mathrm{VO}_{2}\right)\right.$. However there are other points to consider. $\mathrm{VO}_{2}$ is less trying on both the observer and the victim and satisfies the suggestion by Shephard (1972) who says that while haemoglobin levels rise with training an excessive increase in $\mathrm{Hb}$ can result in polycythaemia and the resulting increase in circulation resistance negates any theoretical advantages gained. Yet Cotes et al (1971) claim that $\mathrm{O}_{2}$ transport is the limiting factor in work capacity and thus prefer to study $\mathrm{VO}_{2}$ max.
\end{abstract}

ABSTRACT

The sub maximal oxygen uptake $\left(\mathrm{VO}_{2}\right)$ of 32 trained male middle and long distance runners aged 19.5-36.0 years was determined at five treadmill speeds. There was a significant linear relationship $(p<0.01)$ between $\mathrm{VO}_{2}$ at each of the treadmill speeds and Fat-Free Mass (FFM) and Lean Leg Volume (LLV). To explain the relationship other factors are considered, the most important of which may be the mechanical configuration of muscle and mitochondrial

Apart from the work by Cotes et al 1971 on cyclists, relatively little work has been conducted on the physiological anthropometry of trained athletes, and the relationship between anthropometric parameters and specific athletic skills has not been studied in detail.

\section{SUBJECTS AND METHODS:}

The group studied comprised 32 male athletes who were participating in daily running in their preparation for top level competition. These were students from Loughborough Colleges' Athletics CLub, Loughborough University of Technology Athletics Club and local athletes. Details of the subjects are given in Table I.

Anthropometric Measures: Body density was predicted from the log of the sum of 4 caliper skinfold
TABLE I

\section{Details of the 32 subjects}

$\begin{array}{lll} & \text { Mean } & \text { S.D. } \\ \text { Age } & 23.8 \text { years } & \pm 5.0 \\ \text { Height } & 1.78 \text { metres } & \pm 0.08 \\ \text { Weight } & 66.6 \mathrm{~kg} & \pm 7.46 \\ \text { FFM } & 61.6 \mathrm{~kg} & \pm 6.23 \\ \text { Total Body Fat } & 7.43 \% & \pm 2.45 \\ \text { LLV } & 7.10 \text { litres } & \pm 1.10\end{array}$

thicknesses (Durnin and Rahaman 1967) where the error has been estimated to be $\pm 3.5 \%$ of body wt., measurements were made on the left side of the body over the biceps, triceps, sub-scapula and supra-iliac regions. The percentage of fat in the body was calculated from the formula of Siri (1961):

\%fat $=\left(\frac{4.95}{D}-4.5\right) \times 100-$ where $D$ is body density in $10^{3} \mathrm{~kg} \cdot \mathrm{m}^{-3}$

Fat-free mass in $\mathrm{kg}$. was calculated by:

$$
F F M=(100-\% \text { fat }) \times W / 100-\text { where } W \text { is weight in } \mathrm{kg} .
$$

LLV was measured by the method of Jones and Pearson (1969) which partitions the leg into 6 segments which are similar to truncated cones.

Exercise Procedure: It was important from a consideration of the specificity of endurance performers that the subjects under test were examined in an exercise procedure as close as possible to their skill. The subjects were studied at five different work rates on a motor driven treadmill, these were: standing erect, walking at 2 $\mathrm{mph}$., walking at $4 \mathrm{mph}$., jogging at $6 \mathrm{mph}$. and running at $8 \mathrm{mph}$. The subjects exercised for $6 \mathrm{~min}$. at each level allowing $4 \mathrm{~min}$. for equilibration and the last $2 \mathrm{~min}$. providing the actual sample periods. 
$\mathrm{VO}_{2}$ was measured using a Douglas bag which was suspended vertically to reduce resistance. The subjects breathed through a low dead space face mask connected to 2 bags by lightweight $40 \mathrm{~mm}$ dacron tubing. Previously calibrated automatic gas analysers (Servomex ICIA and Hartman Braun) were used to determine the $\mathrm{O}_{2}$ and $\mathrm{CO}_{2}$ contents of the expired air. The expiratory volume was measured by a Parkinson Cowan CD4 gas meter. The calculated $\mathrm{VO}_{2}$ was corrected to STPD.

RESULTS AND DISCUSSION: There was a significant linear relationship between $\mathrm{VO}_{2}$ and FFM, and $\mathrm{VO}_{2}$ and $L L V$ at all the treadmill speeds, $p<0.01$. Figures 1 and 2 show the regression equations, correlation coefficients, coefficients of variation and the standard errors of the estimates (SEE). It can be seen that there is good relationship between the structural parameters and function as measured by $\mathrm{VO}_{2}$. However, two main points arise:

i) the relationships are not constant for different rates of work i.e. there are different slopes.

ii) If $\mathrm{VO}_{2}$ was entirely dependent on the amount of muscle, the relationship should approach unity. Anything removed from this value implies that the relationship has been distorted by other variables. This becomes clearer when specificity and generality i.e.

THE RELATIONSHIP BETWEeN $\mathrm{VO}_{2}$ FFM AT VARIOUS TREADMILL SPEEDS

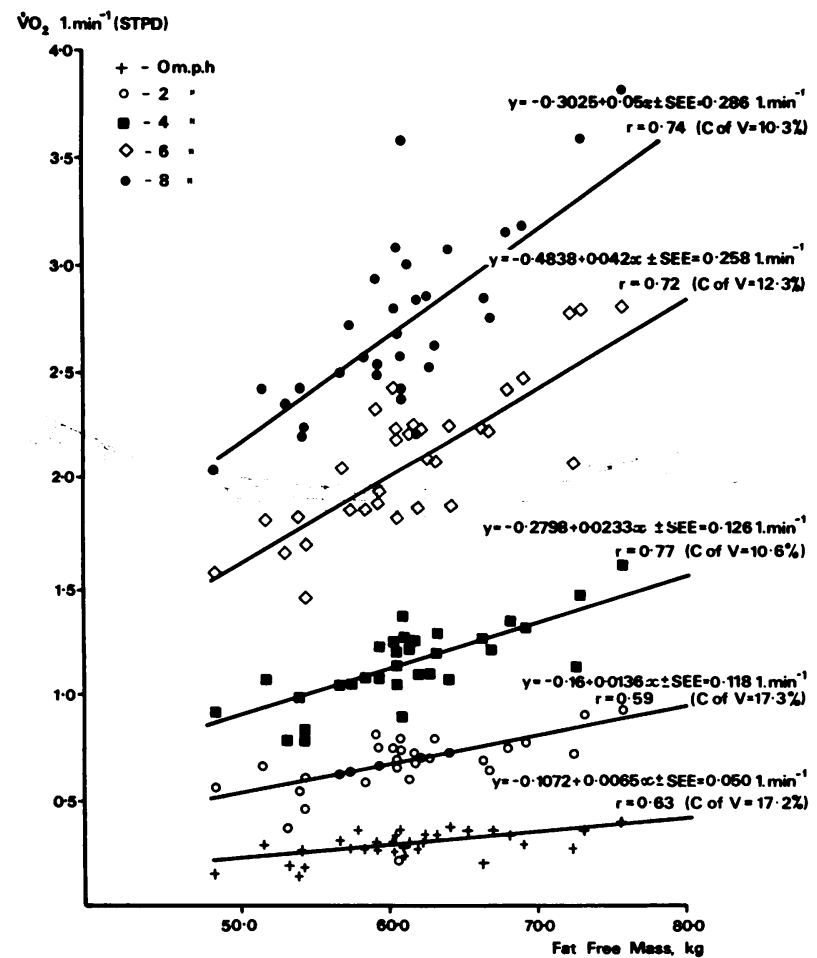

$1-r^{2}$ and $r^{2}$ respectively, are computed and expressed as a percentage. At best only a third of the variance of $\mathrm{VO}_{2}$ is attributable to its relationship with LLV and two-thirds of the variance of $\mathrm{VO}_{2}$ is attributable to its relationship with FFM.

Graham and Andrew (1973) demonstrated that trained subjects had a higher $\mathrm{VO}_{2}$ max than their untrained peers. If one considers the different results of Glassford et al (1965), DeVries (1968), Shephard et al (1968), Åstrand and Rodahl (1970), McArdle and Magel (1970) and of Wyndham (1974) one finds that among highly trained individuals $\mathrm{VO}_{2}$ max differs markedly with the physical skill employed for the work task. Certainly we cannot suggest that the differences are solely dependent on $\mathrm{O}_{2}$ transport and with our own results with highly trained performers giving different slopes for different work rates we suggest we might look at two aspects of muscle function.

First is mechanical configuration of muscle; unfortunately when determining FFM the mechanical configuration of muscle is not taken into account as the calculation is essentially volumetric. Thus utilization of the 'Units' of contraction, which will vary in their action between individuals and skills, may contribute to different effective forces being produced. In endurance

THE RELATIONGHIP BetWEen NO, LLV at VARIOUS TREADMILL SPEEDS

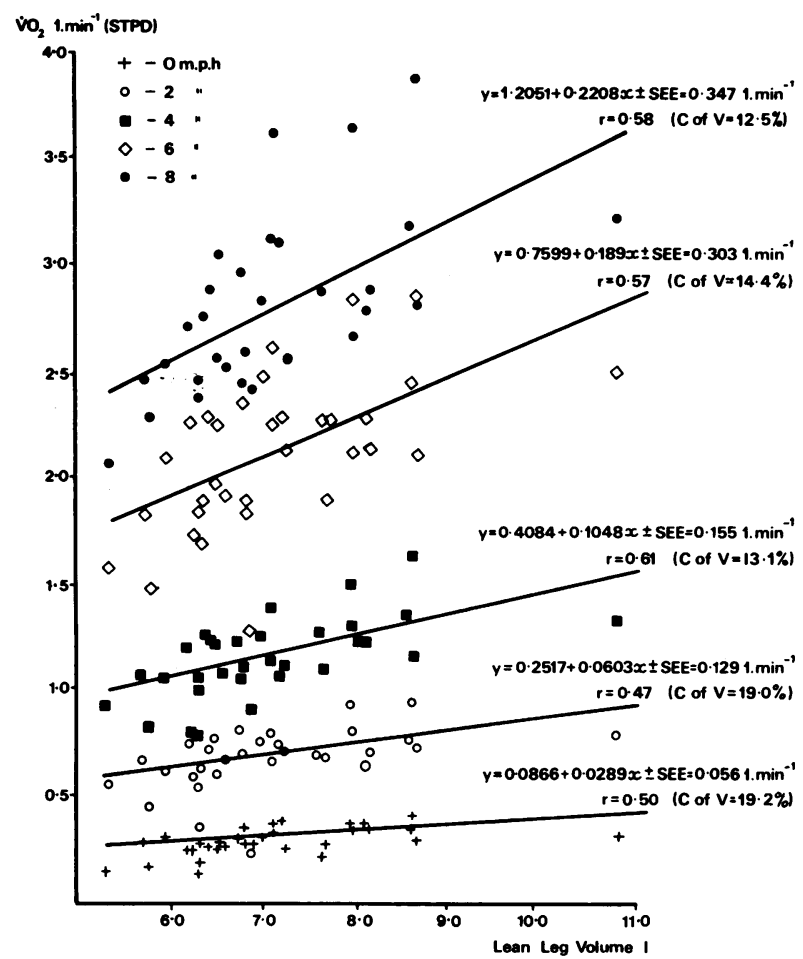


type performances as in these work tasks the cumulative effect could be considerable.

Second is mitochondial function; Holloszy (1967) demonstrated that the mitochondria in striated muscle undergo adaptive changes both in number and composition as a result of training. He also showed that the pertinent enzyme systems develop most in the most active muscles. This will have considerable bearing on the efficiency of energy production and shows that $\mathrm{O}_{2}$ utilisation at a specific cell site may be more important than previously thought.
If we take both these arguments it may be possible to explain why an international class performer in one skill is not seen to be as effective in another. Thus to perfect a given pattern of muscular activity to its ultimate capability, the training rates must be intense and must be specifically related to the muscular systems involved in the skill. However, considerably more work in this area is needed.

\section{ACKNOWLEDGEMENT:}

We are most grateful to Dr. P. R. M. Jones for help with the anthropometric parts of this study.

\section{REFERENCES}

ÅsTRAND, P-O. and RODAHL, K., 1970. Textbook of Work Physiology. McGraw-Hill, London.

COTES, J. E., DAVIES, C. T. M., EDHOLM, O. G., HEALY, M. J. R. and TANNER, J. M., 1969. Factors relating to the aerobic capacity of 46 healthy British males and females aged 18-28 years. Proc. Royal Soc.Med.B. 174, 91-114.

COTES, J. E., DABBS, J. M., DALEY, C., HALL, A. M., JOHNSON, G. R., REED, S. W. and SAUNDERS, J. M., 1971. Above average exercise capacity in competition cyclists; relationship to body muscle. J.Physiol. 281, 63-64p.

DeVRIES, H. A., 1968. The physiology of exercise. Staples, London.

DURNIN, J. V. G. A. and RAHAMAN, M. M., 1971. The assessment of the amount of fat in the human body from measurements of skinfold thickness. Br.J. Nutn. 21, 681-689.

GLASSFORD, R. G., BANCROFT, G. H. V., SEDGEWICK, A. W. and MCNAB, R. B. J., 1965. A comparison of maximal oxygen uptake values determined by predicted and actual methods. J.Appl.Physiol. 20, 509-513.

GRAHAM, T. E. and ANDREW, G. M., 1973. The variability of repeated measurements of $\mathrm{O}_{2}$ debt in man following a maximal treadmill exercise. Med.Sci.in Sport. 5, 73-78.

HAMLEY, E. J. and WATSON, R., 1969. The relationship of maximum oxygen uptake to lean leg volume in young female P.E. students. J.Physiol. 206, 2-4p.

HOLLOSZY, J. O., 1967. Biochemical adaptation in muscle. The effects of exercise on mitochondrial oxygen uptake and respiratory enzyme activity in skeletal muscle. J.Biol.Chem. 242, 2278-2282.

JONES, P. R. M. and PEARSON, J., 1969. An anthropometric determination of leg fat and muscle plus bone volumes in male and female adults. J.Physiol. 204, 63-66p.

JONES, P. R. M., COTES, J. E., KNIBBS, A. V. and BIRKINSHAW, L. W., 1970. The contribution of indices of leg muscle to maximum oxygen uptake. Ergonomics, 13, 529.

McARDLE, W. D. and MAGEL, J. R., 1970. Physical work capacity and maximum oxygen uptake in treadmill and bicycle exercise. Med.Sci.in Sport. 2, 118-123.

SHEPHARD, R. J., ALlen, C., BENADE, A. J. S., DAVIES, C. T. M., PRAMPRERO, P. E., HEDMAN, R., MERRIMAN, J. E., MYHRE, K. and SIMMONS, R., 1968. Maximum oxygen intake. (An international reference standard of cardiorespiratory fitness.) Bull.W.H.O. 38, 757-764.

SHEPHARD, R. J., 1972. Cardiorespiratory endurance. New Zealand J.Health, Phys. Ed.\&Rec. (res.issue) 1972.

SIRI, W. R., 1961. Body composition from fluid spaces and density; analysis of methods. In: Techniques for measuring body composition Ed. Brozek, J. and Henschel, A., pp 223-244. Nat.Acad.Sci.Washington D.C.

WYNDHAM, C. H., 1974, in: The validity of physiological determinations in fitness health and work-capacity. Ed. Larson, L. A., Macmillan, New York. 